\title{
Dairy Cow Welfare, Heat Stress and Climate Change
}

\author{
David Williams* \\ Department of Veterinary Medicine, University of Cambridge, UK
}

Submission: December 10, 2018; Published: December 17, 2018

*Corresponding author: David Williams, Department of Veterinary Mediicne, University of Cambridge, Cambridge CB3 0ES, UK,

Email: dlw33@cam.ac.uk

\section{Abstract}

There has been widespread concern in the media regarding the impact that livestock have on global warming, particularly with methane from ruminants noted as a potent greenhouse gas. Less public debate has occurred however, on the potentially negative impact that global warming will have, indeed is having, on livestock welfare. Here we will first briefly discuss the effect of livestock husbandry on climate change before moving to a more detailed discussion of the effect that a warmer climate is likely to have, again is currently having, on the physiology and welfare of cattle across the world. Finally, we will briefly discuss measures that can be taken to reduce the impact of temperature increase on dairy cattle.

\section{Introduction}

Recent research has estimated that while cattle provide just $18 \%$ of the world's dietary calories and $37 \%$ of protein, they use a huge proportion (83\%) of agricultural land and produce $60 \%$ of agricultural greenhouse gas emissions [1]. Understandably, given these figures, most public concern regarding cattle and climate change has focussed on the animals as an important causative agent with broadcast media highlighting the problem [2]. Public understanding of the impact of global warming on cattle welfare is significantly less, although some newspapers have noted the problem [3]. The effects of heat stress on beef and dairy cattle have been recognised by the farming industry for some time but the link with increasing ambient temperature is only recently being highlighted. Here we look at the effects of heat stress on cattle and the impact that global warming will have, indeed is already having, on cattle welfare.

\section{Heat Stress and the Lactating Cow}

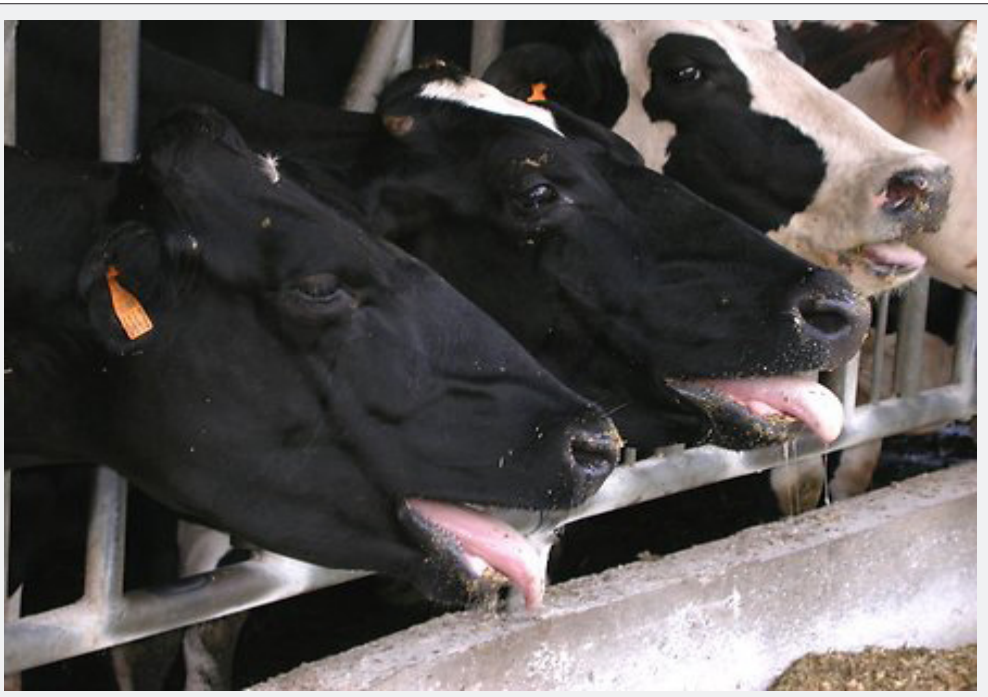

Figure 1: Dairy cattle showing clear respiratory signs of heat stress (Solvay). 
The lactating dairy cow already has an increased internal temperature through her milk production (Figure 1). Heat production through metabolic functions is estimated to account for around a third of the energy intake of a $600 \mathrm{~kg}$ cow producing $40 \mathrm{~kg}$ of milk daily with a far level of 4\% [4]. A study comparing cows that were non-lactating, or at low $(18.5 \mathrm{~kg} / \mathrm{d})$ or high $(31.6 \mathrm{~kg} / \mathrm{d})$ milk yield showed that low and high yielding cows generated 27 and $48 \%$ more heat than nonlactating cows even though they had a lower body weight [5]. Whilst in cold environments dissipation of such body heat is not a problem, during periods of elevated ambient temperature, heat loss can be a significant problem for dairy cattle. The limiting factor for cattle at peak lactation is energy intake and a common management practice is to increase energy density of the diet by decreasing forage and giving a mixed ration with a high energy density. A side effect of feeding such a high energy ration is that of increased heat production; Reynolds and colleagues showed that heat production for heifers ingesting 4 and $7 \mathrm{~kg}$ dry matter per day was around 40 and $56 \mathrm{MJ} / \mathrm{d}$ respectively [6].

The irony, if we are aiming to increase dietary intake in cattle living on the metabolic knife edge of maximum productivity, is that heat stress leads to reduced feed intake, decreased activity and increase in peripheral blood flow to aid perspiration [7] while decreasing portal blood flow taking nutrients from the intestines to the liver [8]. Lough's 1990 paper also showed a reduced vascular supply to the mammary gland in times of heat stress, reducing milk production. Other effects of heat stress on lactation include a decline in plasma somatotrophin and triiodothyronine and thyroxine [9]. Heat stress alters blood acid-base balance, since panting animals lose carbon dioxide and thus have a respiratory alkalosis [10]. Compensation for this involves increased renal excretion of bicarbonate in times of heat stress, leading to a paradoxical metabolic acidosis during the cooler hours of nighttime. This in turn leads to a loss of bicarbonate buffering capacity which can be critical if cattle are being fed high grain rations. To add to the cow's electrolyte compromise, potassium loss through increased sweating can lead to hypokalaemia [11].

What impact do these metabolic changes in heat stress have on the affective status of the animal? As far back as 1968 Collins and Weiner suggested that acute heat stress had emotional effects on dairy cattle [12] and subsequent work confirmed that heatstressed cattle have higher cortisol levels than animals kept in cooler environments [13]. Animals with a reduce dry matter intake during heat stress are not only physiological stressed, losing body weight, but also emotionally affected by hunger [14]. We know that cattle given a limited grazing period have higher plasma levels of ghrelin, the 'hunger hormone' [15] and it is reasonable to assume that cattle reducing their dietary intake through heat stress will experience the same endocrinologic and affective state. Thirst too is a classic response to heat stress and providing adequate water is essential [16] with chilled drinking water alleviating both thermal issues and thirst $[17,18]$. Stermer's research [17] was undertaken more than thirty years ago and yet it must be asked how many farms are providing chilled water for their dairy cattle in times of heat stress. Such information is difficult to access, but this author's impression is that few are.

What influence does heat stress have on lameness and pain in dairy cattle? Heat-stressed cattle increase their standing time to allow greater body surface area to be exposed to the air for heat loss by convection. Lying time is reduced by $30 \%$ with higher ambient temperatures [19] and increased periods of standing have been suggested as a significant risk factor for lameness which is already a substantial cause of pain in a sizeable proportion of dairy cattle [20]. It has been suggested that the conflict between whether to stand up and increase cooling or to lie and relieve pain form lameness might be a significant factor in frustration in dairy cattle, a potentially important affective influence on their welfare [21]. Leg stomping, weight repositioning and butting, potential behavioural indicators of frustration, have been noted in cattle deprived of the opportunity to lie [22] and it would be a valuable exercise to assess the prevalence of such behaviours in heat stressed cattle as compared with the same animals in cooler environments.

Heat stress also reduces fertility in cattle. While results of research on the effect of heat stress on reproductive endocrine status have been varied, plasma luteinising hormone pulses have been shown to be of lower amplitude and frequency in periods of high ambient temperature [23] and plasma oestradiol concentrations are lowered by heat stress in dairy cows. Plasma progesterone levels are influenced by food intake and hepatic metabolism as well as luteal function, so the influence of heat stress on progesterone production is complex, but effects of heat stress on this hormone will affect the survival of an implanting fetus in the uterine wall as well as oocyte formation with deleterious effects on oocyte maturation and embryonic death.

\section{Opportunities to Alleviate These Issues}

Ambient temperature increases are to be expected in the future, so one must ask what measures can be put in place to manage heat stress in cattle. A personal experience might be worth noting here. On a visit to the Department of Veterinary Medicine in the University of Khartoum, Sudan I was at first horrified to see Holstein Friesian cattle, imported from Holland, kept in the elevated temperatures of this African country. Inspection of the farms however showed the use of large water misting fans to cool the cattle (Figure 2). This together with adequate provision of shade allowed the cattle to live comfortably. Indeed, the human inhabitants of Khartoum have borrowed that technology and now use water-cooling fans in up-market restaurants in the city! It is not only equatorial Africa which is using such technology in the livestock industry. American and Australian dairy farms are now also using fan assisted cooling and sprinklers more and more [24]. With an estimated reduction in lactation of up to $35 \%$ in midlactating heat-stressed cows it has been suggested that the US dairy industry is losing between $\$ 900$ and $\$ 1500$ million annually [25]. Clearly reducing heat stress is not only a welfare issue, but also a commercial imperative. 


\section{Journal of Dairy \& Veterinary Sciences}

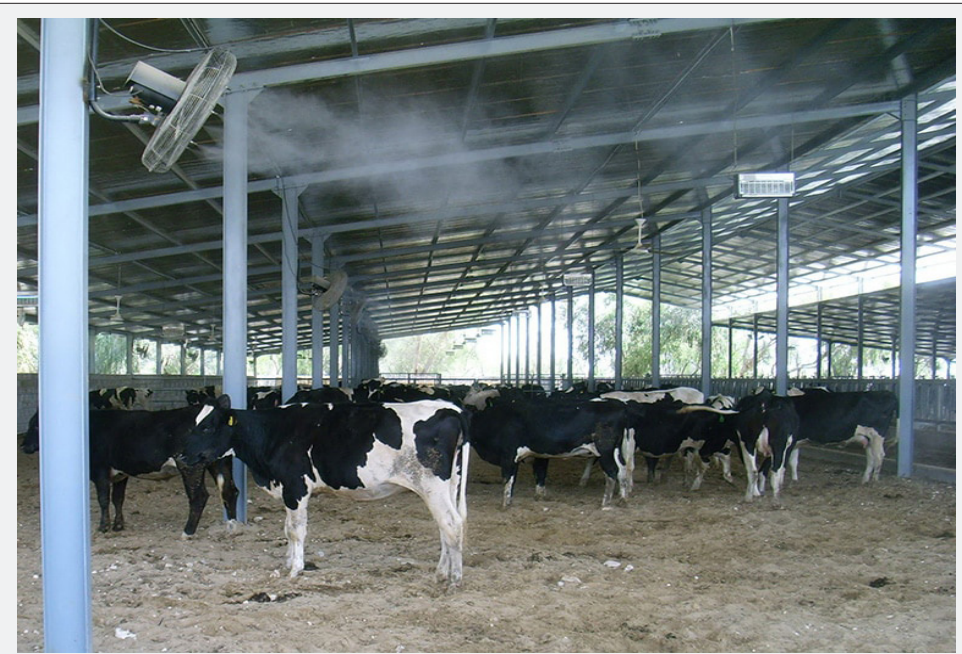

Figure 2: Misting fans can significantly reduce heat stress (Masterkool).

\section{References}

1. Poore J, Nemecek T (2018) Reducing food's environmental impacts through producers and consumers. Science. 360(6392): 987-92.

2. Carrington D (2018) Avoiding meat and dairy is 'single biggest way' to reduce your impact on Earth.

3. Foskolos A, Moorby J (2018) How climate change will impact cows and the dairy industry.

4. Coppock CE (1985) Energy nutrition and metabolism of the lactating dairy cow. J Dairy Sci 68: 3403-3410.

5. Purwanto BP, Abo Y, Sakamoto R, Furumoto F, Yamamoto S (1990) Diurnal patterns of heat production and heart rate under thermoneutra conditions in Holstein Friesian cows differing in milk production. Journal of Agricultural Science 114: 139-142.

6. Reynolds CK, Tyrrell HF, Reynolds PJ (1991) Effects of diet forage-toconcentrate ratio and intake on energy metabolism in growing beef heifers: whole body energy and nitrogen balance and visceral heat production. Journal of Nutrition 121: 994-1003.

7. Lough DS, Beede DL, Wilcox CJ (1990) Effects of Feed Intake and Thermal Stress on Mammary Blood Flow and Other Physiological Measurements in Lactating Dairy Cows. Journal of Dairy Science. 73 325-332.

8. McGuire MA, Beede DK, DeLorenzo MA, Wilcox CJ, Huntington GB, et al. (1989) Effects of thermal stress and level of feed intake on portal plasma flow and net fluxes of metabolites in lactating Holstein cows Journal of Animal Science 67: 1050-1060.

9. McGuire MA, Beede DK, Collier RJ, Buonomo FC, DeLorenzo MA, et al. (1991) Effects of acute thermal stress and amount of feed intake on concentrations of somatotropin, insulin-like growth factor (IGF)-I and IGF-II, and thyroid hormones in plasma of lactating Holstein cows Journal of Animal Science. 69: 2050-2056.

10. Srikandakumar A, Johnson EH (2004) Effect of heat stress on milk production, rectal temperature, respiratory rate and blood chemistry in Holstein, Jersey and Australian Milking Zebu cows. Tropical animal health and production. 36(7): 685-692.

11. Jenkinson DM, Mabon RM (1973) The effect of temperature and humidity on skin surface $\mathrm{pH}$ and the ionic composition of skin secretions in Ayrshire cattle. British Veterinary Journal. 129: 282-295.

12. Collins KJ, Weiner JS (1968) Endocrinological aspects of exposure to high environmental temperatures. Physiological Reviews. 48: 785-839.
13. Wise ME, Armstrong DV, Huber JT, Hunter R, Wiersma F (1988) Hormonal Alterations in the Lactating Dairy Cow in Response to Thermal Stress1. Journal of Dairy Science. 71: 2480-2485.

14. Roche JR, Friggens NC, Kay JK, Fisher MW, Stafford KJ, et al. (2009) Invited review: Body condition score and its association with dairy cow productivity, health, and welfare. Journal of dairy science. 92(12): 5769-5801.

15. Gregorini P, Clark CE, Jago JG, Glassey CB, McLeod KL, et al. (2009) Restricting time at pasture: effects on dairy cow herbage intake, foraging behavior, hunger-related hormones, and metabolite concentration during the first grazing session. Journal of Dairy Science 92: $4572-4580$

16. West JW (2003) Effects of heat-stress on production in dairy cattle. Journal of Dairy Science 86: 2131-2144.

17. Stermer RA, Brasington CF, Coppock CE, Lanham JK, Milam KZ (1986) Effect of Drinking Water Temperature on Heat Stress of Dairy Cows. Journal of Dairy Science. 69: 546-551.

18. Wilks DL, Coppock CE, Lanham JK, Brooks KN, Baker CC, et al. (1990) Responses of lactating Holstein cows to chilled drinking water in high ambient temperatures. Journal of Dairy Science 73:1091-1099.

19. Cook NB, Mentink RL, Bennett TB, Burgi K (2007) The effect of heat stress and lameness on time budgets of lactating dairy cows. Journal of Dairy Science 90: 1674-1682.

20. Cook NB, Nordlund KV (2009) The influence of the environment on dairy cow behavior, claw health and herd lameness dynamics. The Veterinary Journal 179: 360-369.

21. Polsky L, von Keyserlingk MA (2017) Invited review: Effects of heat stress on dairy cattle welfare. Journal of dairy science 100: 8645-8657.

22. Cooper MD, Arney DR, Phillips CJ (2007) Two-or four-hour lying deprivation on the behavior of lactating dairy cows. Journal of Dairy Science 90(3): 1149-1158.

23. De Rensis F, Scaramuzzi RJ (2003) Heat stress and seasonal effects on reproduction in the dairy cow-a review. Theriogenology. 60(6): 11391151

24. Fournel S, Ouellet V, Charbonneau É (2017) Practices for alleviating heat stress of dairy cows in humid continental climates: a literature review. Animals 7: 37

25. St-Pierre NR, Cobanov B, Schnitkey G (2003) Economic losses from heat stress by US livestock industries. Journal of Dairy Science 86: E5277. 
This work is licensed under Creative Commons Attribution 4.0 License

DOI: 10.19080/JDVS.2018.08.555746

\section{Your next submission with Juniper Publishers} will reach you the below assets

- Quality Editorial service

- Swift Peer Review

- Reprints availability

- E-prints Service

- Manuscript Podcast for convenient understanding

- Global attainment for your research

- Manuscript accessibility in different formats ( Pdf, E-pub, Full Text, Audio)

- Unceasing customer service

Track the below URL for one-step submission https://juniperpublishers.com/online-submission.php 